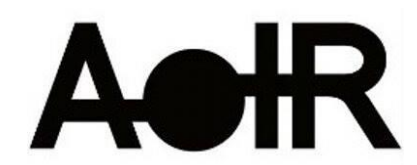

Selected Papers of \#AoIR2021:

The 22nd Annual Conference of the

Association of Internet Researchers

Virtual Event / 13-16 Oct 2021

\title{
NO CLOUD WITHOUT SKY: SPECTRUM SOVEREIGNTY AND ETHEREAL REFUSAL
}

\author{
Author \#1 Jeff Gagnon \\ Author \#1 University of Toronto
}

\begin{abstract}
Recently, the expression of numerous concerns has tempered early enthusiasm for digitally-enabled activism which has lead Sylvia Federici to caution against a view that "digital technologies are conveyor belts of global revolution" (Federici 2019, p. 193). These technologies are not inherently emancipatory or even politically agnostic, but are inseparable from the physical, social, and economic infrastructures and disciplinary regimes that produce them.
\end{abstract}

Within anticolonial contexts, communications technologies are always haunted by dependence on ongoing territorial dispossession, resource exploitation and treaty violations. In the wake of Idle No More, Leanne Betasamosake Simpson has expressed concern that for all its successes, the movement could never fully actualize radical Indigenous resurgent practices ("grounded normativity") because of the internet's inherent functioning as a reinforcement and amplification of settler colonial relations (Simpson 2017). Moreover, Simpson argues that grounded normativity, being a placebased practice, and decolonialism more generally, being about land and territory, are irreconcilable with the ethereal "landlessness" of cyberspace.

This conceptual disconnection of the internet from land and territory therefore renders it unsustainable as a site for Indigenous resistant practices and decolonial mobilizations. While valuable movements in support of Indigenous data sovereignty (Brown \& Nicholas 2012; Kukutai \& Taylor 2016), digital equity and network access (Toth, Smith \& Giroux 2018; Mnzm 2019) have proliferated in recent years, these movements only address the symptoms of settler colonialism, these approaches do not or cannot address the material and territorial factors at play in the internet's relationship to settler colonialism. Digitally-enabled activism has a space problem: etherealist understandings of cyberspace allow settler colonial spatial supremacies to evade transformative decolonial liberatory practices. Colonialism is a question of land and territory, land and territory upon which communications networks depend for raw materials and through which they move. These spatial configurations and their concomitant socio-economic

Suggested Citation (APA): Gagnon, J. (2021, October). No Cloud Without Sky: Spectrum Sovereignty and Ethereal Refusal. Paper presented at AolR 2021: The 22nd Annual Conference of the Association of Internet Researchers. Virtual Event: AolR. Retrieved from http://spir.aoir.org. 
relations become the unseen and uncritiqued ground upon which digitally mobilized movements are dependent. Decolonization, in this context, remains metaphorical (Tuck \& Yang 2012) rather than being a material refusal of territorial dispossession.

No Cloud Without Sky is a new postdoctoral project that considers spectrum sovereignty (the application of Indigenous title to radio and broadband networks) as a response to the spatial problem articulated above. This paper introduces the project, its theoretical frameworks, ethical standpoint, research questions, and preliminary findings. This overview is a preliminary step toward a multiyear, international (Canada, USA, New Zealand, Australia) survey and case-study based project that aims to convene a space for the advancement of decolonized internet and communications networks predicated on the production of relational knowledges and the promotion of international solidarities. Centering the materiality of cyberspace necessarily reveals the relationships between the internet and settler colonialism. Such an acknowledgement is foundational to a decolonialist ethical point of view from which I argue for an understanding of space as relational practice, as resource, and as source of identity. A decolonized cyberspace that promotes the independence of colonized peoples is one that is subject to Indigenous spatial practices including territorial claims and treaty rights and so is one that is recognized as existing within space in a material way. As Chief Ovide Mercredi has once said, such a demand is "based on the understanding that we do have some fundamental rights as Indigenous people to land, water, and airspace" (CBC News 2007).

My research is multi-disciplinary and combines the work of scholars and activists in critical geography, decolonial studies, Internet studies, feminist theory, and Indigenous resurgence. The spatial ethics articulated by Henri Lefebvre, Doreen Massey, and Sylvia Federici are foundational to how I understand the relationship between individuals, space, and the state. These theoretical positions reinforce arguments made by Glen Coulthard and Leanne Simpson that promote Indigenous grounded normativity as a mode of place-based solidarity that supports relational politics and Indigenous resurgence. Inherent in such practices is the notion of "refusal," which Audra Simpson proposes as a rejection of the conceptual frameworks that legitimize territorial dispossession as a fait accompli (Simpson 2014). The withdrawal of consent to settler colonial narratives includes a disruption of spatial configurations that erase Indigenous territory. It is against such erasure that this work brings together critical geographies of space and Indigenous resurgence theories alongside the work of scholars who discuss digital sovereignty (Bratton 2015; Srnicek), internet ethics (Zuboff 2019), and the geography of cyberspace (Cohen 2007; Graham 1998) in order to identify how the refusal of etherealist notions of cyberspace that privilege settler colonial spatial hierarchies is made manifest within movements for spectrum sovereignty.

\section{References}

Bratton, Benjamin H. The Stack: On Software and Sovereignty. MIT Press, 2015.

Brown \& Nicholas. "Protecting Indigenous Cultural Property in the Age of Digital Democracy." Journal of Material Culture, Vol. 17, Issue 3. September 11, 2012. 
Cameron, Aidan. "Maori Rights in the 4G Radio Spectrum: Fantasy or the Future of Treaty Claims." Otago Law Review, Vol. 13, No. 1, 2013, pp. 181-196.

https://heinonline.org/HOL/P?h=hein.journals/otago13\&i=185\&a=dXRvcm9udG8uZWR1

Castells, Manuel. Networks of Outrage and Hope. Polity, 2012.

CBC News. "Manitoba Chiefs Want Cellphone Revenue." May 30, 2007. https://www.cbc.ca/news/manitoba-chiefs-want-cellphone-revenue-1.662690

Cohen, Julie E. "Cyberspace As/And Space." Columbia Law Review. 107;210. 2007, pp. 210-256.

Coulthard, Glen Sean. Red Skin White Masks. University of Minnesota Press, 2008.

Croeser, Sky. Global Justice and the Politics of information. Routledge, 2015.

Duarte, Marisa Elena. Network Sovereignty: Building the Internet Across Indian Country. University of Washington Press, 2017.

Earl, Jennifer and Kimport, Katrina. Digitally Enabled Social Change. MIT Press, 2011.

Everton, Graeme. "A $5 \mathrm{~g}$ Network is Coming and Māori Deserve a Share." The Spinoff. Nov. 8, 2018.

https://thespinoff.co.nz/atea/08-11-2018/a-5g-network-is-coming-and-maori-deserve-ashare/

Federici, Sylvia. Re-Enchanting the World. Kairos, 2019.

Fisher, Mark. Capitalist Realism: Is there no Alternative? Zero Books, 2009.

Fuentes, Marcela A. Performance Constellations: Networks of Protest and Activism in Latin America. University of Michigan Press, 2019.

Gagnon, Jeff. Tactical Dramaturgies: Media, the State, And the Performance of PlaceBased Activism. PHD Dissertation. University of Toronto, 2020.

Graham, Stephen. "The end of geography or the explosion of place?" Progress in Human Geography. 22, 2. 1998. Pp. 165-185.

Han, Byung-Chul. Psychopolitics: Neoliberalism and New Technologies of Power. Verso, 2017.

Hardt, Michael and Negri, Antonio. Assembly. Oxford, 2017.

Harp, Rick. "Spectrum Sovereignty? Maori Treaty Rights to $4 \mathrm{~g}$ Debated in New Zealand." Medialndigena.com. June 21, 2010.

https://mediaindigena.com/spectrum-sovereignty-maori-treaty-rights-to-4g-debated-innew-zealand/ 
Joyce, Zita. "Radio Spectrum as Indigenous Space." In Taylor Gregory and Middleton, Catherine (eds.) Frequencies: International Spectrum Policy. McGill-Queen's University Press, 2020.

Kukutai, Tahu and Taylor, John. Indigenous Data Sovereignty: Toward an Agenda. Australian National University, 2016.

Lefebvre, Henri. The Production of Space. Nicholson-Smith, Donald, trans. Blackwell, 2012.

Massey, Doreen. "Power-geometry and a progressive sense of place." Mapping the Futures: Local Cultures, Global Change. Bird, Jon, ed. Routledge, 1993.

Mnzm, Laurence Zwimpfer. "A Digital Inclusion Blueprint and Online Resilience." Collected Magazine, 2019, p.32.

Simpson, Audra. Mohawk Interruptus. Duke University Press, 2014.

Simpson, Leanne Betasamosake. As We Have Always Done. University of Minnesota Press, 2017.

---. A Short History of the Blockade. University of Alberta Press, 2021.

Srnicek, Nick. Platform Capitalism. Polity, 2017.

Toth, Smith, and Giroux. "Indigenous Peoples and Empowerment via Technology." First Peoples Child \& Family Review. Vol. 13, No. 1. 2018.

Sinclair, Murray et. Al. Final Report of the Truth and Reconciliation Commission of Canada. Lorimer, 2015.

Tuck, Eve \& Yang, K. Wayne. "Decolonization is not a Metaphor." Decolonization, Vol. 1, No. 1, 2012, pp. 1-40.

Waitangi Tribunal. Report of the Waitangi Tribunal on Claims Concerning the Allocation of Radio Frequencies. Wai 26/150, 1990.

https://forms.justice.govt.nz/search/Documents/WT/wt_DOC_68476762/Allocation\%20o f\%20Radio\%20Frequencies\%201990.pdf

Wemigwans, Jennifer. A Digital Bundle. University of Regina Press, 2018. 